\title{
Threats to Brazilian crocodilian populations
}

\author{
P. Brazaitis, George H. Rebêlo, Carlos Yamashita, Elizabeth A. Odierna \\ and Myrna E. Watanabe
}

Brazilian crocodiles are threatened by gold mining and related mercury-and leadcontamination of animals and their habitat, deforestation, increasing use of land for agriculture and destructive forestry, increased human incursions, and commercial and subsistence hunting for skins and meat. Contaminated meat is consumed by local people and miners, and meat and skins are exported to global markets. Already depleted black caiman Melanosuchus niger populations are seriously affected.

\section{Introduction}

Between 1985 and January 1992, field investigations were conducted throughout Brazil (Brazaitis et al., 1988, 1990, 1992) to determine the distribution of caiman species and populations, and to collect biological samples for additional studies. The field studies also afforded the author the opportunity to field-test experimental toxic-metal-contamination indicator products, and observe environmental conditions, political considerations and threats that affect the status and conservation of Brazilian caiman species. This paper reports the results of those observations, and identifies and calls attention to emerging threats, particularly for the regions of northern Brazil. This paper does not attempt to quantify the extent or long-term impact of toxic metal contamination on wild populations of crocodilians. Such quantification can be accomplished only by undertaking long-term focused studies.

Brazilian caiman populations are important for the taxonomic and ecological study of caiman species. Six species of caiman occur in Brazil (Carvalho, 1951; Medem, 1983; Table 1), which includes the primary range of distribution for the common caiman Caiman crocodilus crocodilus and the black caiman Melanosuchus niger. Some species, such as C. $c$. crocodilus, the Yacare caiman $C$. yacare, the broad-snouted caiman $C$. latirostris and $M$. niger, are of great commercial interest. Their skins are of economic value to international, national and local industries, and are used to produce novelty leather for the manufacture of products that are globally distributed. Brazilian caiman have been the target of intensive hunting pressures, both legal and illegal, for the international commercial leather trade (Brazaitis, 1990; Medem, 1983; Thorbjarnarson, 1992). All the Brazilian species are sought for meat and are frequently the target of subsistence hunting by local people.

The Convention on International Trade in Endangered Species of Wild Fauna and Flora (CITES) lists $M$. niger and $C$. latirostris in Appendix I, prohibiting them from international commercial trade. All other Brazilian caiman are listed under CITES Appendix II (Table 1), allowing them into commercial trade with national and CITES permits. Caiman yacare is listed in Appendix II of CITES, but is prohibited from import into the USA for commercial purposes under the US Endangered Species Act, 1973 (ESA). In addition, the US Lacey Act allows for the prosecution of violations involving species under the protection of national laws of foreign countries. Thus, because Brazil prohibits the commercial hunting of wildlife under Act 5197 of 1967, all wild-caught Brazilian caiman, regardless of their CITES or ESA listing, are prohibited from US commercial trade. 


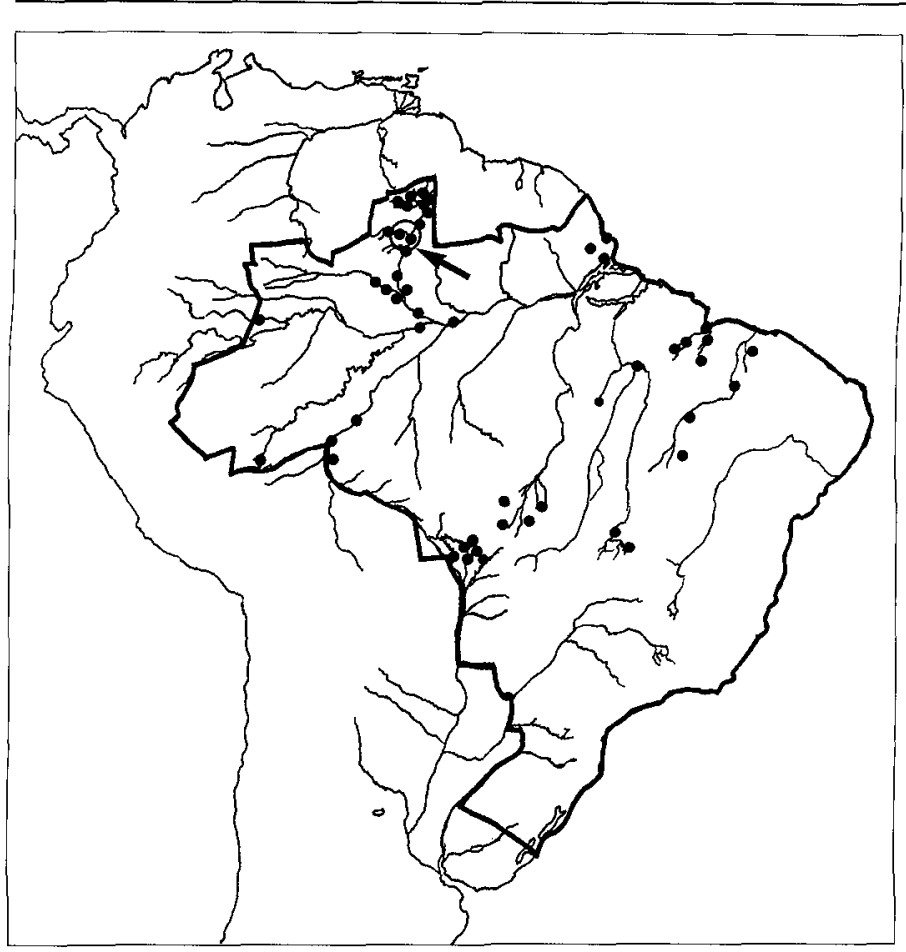

Figure 1. Map of Brazil indicating regions of investigation. The arrow indicates region of mercury test sites, state of Roraima: at the middle reaches of the Rio Branco, Praia do Brazil; Rio Ajarah, at Ilha da Viura, approximately 20 $\mathrm{km}$ upstream from the Rio Branco; and at the mouth of the Rio Mucajai where it joins the Rio Branco.

Table 1. Status and distribution of Brazilian caiman species

\begin{tabular}{|c|c|c|c|c|}
\hline Scientific name & English name & $\begin{array}{l}\text { IUCN } \\
\text { Red List } \\
1994^{*}\end{array}$ & CITES & Distribution \\
\hline $\begin{array}{l}\text { Caiman crocodilus } \\
\text { crocodilus }\end{array}$ & Common caiman & LR & $\begin{array}{l}\text { App. II } \\
\text { Parnaiba } \\
\text { Xingú ri }\end{array}$ & $\begin{array}{l}\text { Rio Solimões, Rio Amazonas, } \\
\text { Araguaia, Araguari, Itapicuru, } \\
\text { Negro, Tapajós, Tocantins, } \\
\text { r drainages }\end{array}$ \\
\hline Caiman yacare & Yacare caiman & LR & $\begin{array}{l}\text { App. II } \\
\text { Rio Mad } \\
\text { Mamore } \\
\text { Rio Para } \\
\text { Pantana } \\
\text { Grosso a }\end{array}$ & $\begin{array}{l}\text { Central and southern Brazil: the upper } \\
\text { ra; drainages of the Rio } \\
\text { lio Guapore, Rio Paraguay, } \\
\text {; wet grasslands and } \\
\text { egions of the states of Mato } \\
\text { Mato Grosso do Sul }\end{array}$ \\
\hline Caiman latirostris & Broad-snouted caiman & LR & $\begin{array}{l}\text { App. I } \\
\text { of Brazil } \\
\text { south to } \\
\text { Argentir } \\
\text { (Yanosk }\end{array}$ & $\begin{array}{l}\text { Eastern highlands and coastal regions } \\
\text { om the Rio San Francisco } \\
\text { ruguay, south-west to } \\
\text { elevations up to } 800 \mathrm{~m} \\
\text { 1994) }\end{array}$ \\
\hline Melanosuchus niger & Black caiman & EN & App. I & Amazon basin and drainages \\
\hline $\begin{array}{l}\text { Palaeosuchus } \\
\text { palpebrosus }\end{array}$ & Dwarf caiman & LR & $\begin{array}{l}\text { App. II } \\
\text { the basir }\end{array}$ & $\begin{array}{l}\text { Throughout Brazil, not including } \\
\text { f the Pantanal }\end{array}$ \\
\hline $\begin{array}{l}\text { Palaeosuchus } \\
\text { trigonatus }\end{array}$ & $\begin{array}{l}\text { Smooth-fronted } \\
\text { caiman }\end{array}$ & LR & App. II & $\begin{array}{l}\text { Black water forest streams of the } \\
\text { Amazon basin }\end{array}$ \\
\hline
\end{tabular}

${ }^{*}$ LR, Lower risk; EN, Endangered. 


\section{Methods and tests}

\section{Observations and data collection}

The primary survey investigations, from which these data are derived, were reported by Brazaitis et al. (1988, 1990, 1992). Fifty-one localities in the Brazilian states of Acre, Amapá, Amazonas, Goiás, Maranhão, Mato Grosso, Pará, Piauí, Rondonia and Roraima were visited during the course of these studies
(Tables 2 and 3). Figure 1 indicates the regions where mercury investigations were conducted.

Expeditions were planned to investigate localities where caiman populations were known to exist, based on the field experience of Brazilian colleagues, the scientific literature, localities represented by specimens in museum collections, and extensive interviews with local people and regional biologists in

Table 2. Brazil study localities included in caiman lead determination studies

\begin{tabular}{|c|c|c|c|}
\hline Location & State & River & Locality \\
\hline 1 & Acre & Rio Branco & Brasilia \\
\hline 2 & Amapá & Rio Araguari & Lago Queimado \\
\hline 3 & Amapá & Rio Araguari & Igarape do Bispo \\
\hline 4 & Amapá & Rio Araguari & Pracuuba \\
\hline 5 & Amazonas & Rio Solimões & Manaus $/ 80 \mathrm{~km} \mathrm{E}$ \\
\hline 6 & Amazonas & Rio Solimões & Tabatinga \\
\hline 7 & Amazonas & Rio Negro & Xeruini \\
\hline 8 & Amazonas & Rio Negro & Terra Preta \\
\hline 9 & Amazonas & Rio Negro & Baependi \\
\hline 10 & Amazonas & Rio Negro & Apuau \\
\hline 11 & Amazonas & Rio Negro & Anavilhanas \\
\hline 12 & Amazonas & Rio Negro & Jauaperi \\
\hline 13 & Goiás & Rio Tocantins basin & Peixe \\
\hline 14 & Goiás & Rio Tocantins basin & Flores de Goiás \\
\hline 15 & Maranhão & Pindaré/lower & Santa Ines \\
\hline 16 & Maranhão & Pindaré/upper & Buriticupú \\
\hline 17 & Maranhão & Pindaré/upper & Imperatriz \\
\hline 18 & Maranhão & Rio Corda & Barra do Corda \\
\hline 19 & Maranhão & Rio Itapicura & Codó \\
\hline 20 & Maranhão & Rio Itapicura & Saõ Luiz \\
\hline 21 & Mato Grosso & Rio Cabacal & Caramujo \\
\hline 22 & Mato Grosso & Rio Galera & \\
\hline 23 & Mato Grosso & Rio Paraguay & Caceres \\
\hline 24 & Mato Grosso & Rio Paraguay & Pocone \\
\hline 25 & Mato Grosso & Rio Sepotuba & Caceres \\
\hline 26 & Mato Grosso & Araguaia & Itauba \\
\hline 27 & Mato Grosso & Xingú & Canarana \\
\hline 28 & Mato Grosso & Xingú & Sinop \\
\hline 29 & Mato Grosso & Xingú & Paranatinga \\
\hline 30 & Mato Grosso & Xingú & Xavantina \\
\hline 31 & Pará & Xingú & Cachimbo \\
\hline 32 & Piauí & Rio Itaueira & Floriano \\
\hline 33 & Piauí & Rio Longa & Periperi \\
\hline 34 & Piauí & Rio Paranaiba & Terasina \\
\hline 35 & Piauí & Rio Piauí & Saõ Jaoa do Piauí \\
\hline 36 & Rondonia & Rio Madeira & Abuna/Humaita \\
\hline 37 & Rondonia & Rio Mamore & Guajara Mirim \\
\hline
\end{tabular}

Sources: Brazaitis et al. (1988, 1990, 1992); Odierna (unpublished). 
each area. Regions where caiman populations were in decline or thought to be recently extirpated were also investigated. The investigating team generally selected a town or small city within the region to be investigated, with easy access by air, to serve as a base of operations. From there, excursions were made to smaller villages where boats and local fishermen could be hired for nightly forays in search of caiman. People from all walks of life were interviewed to determine: their views and observations on the status of caiman populations; perceived trends in populations; factors affecting those populations; cultural, political and economic factors affecting local interest in hunting caiman; and any knowledge of environmental pollution or contamination. Direct observations on caiman populations (Brazaitis et al., 1996) and their habitats were then made during the course of conducting the primary field surveys to corroborate local opinions and identify any other factors affecting crocodilians.

\section{Heavy metal investigations}

Experimental tests were conducted on river substrates to detect the presence of mercury $(\mathrm{Hg})$ downstream from areas where gold-mining operations were observed in the state of
Roraima (Table 3). Chemcheck for Mercury ${ }^{\mathrm{TM}}$, mercury detection swabs (experimental lot MMH100191) were obtained through the courtesy of HybriVet Systems Inc. Framingham, MA 01701, USA. Meredith Hunter provided test protocols. Prepared applicator swabs react to the presence of mercury at extractable concentrations greater than $2 \mu \mathrm{g}$ by turning the colour of the swab from pink to blue/purple when immersed in an extracted solution prepared from the material to be tested. The prescribed extraction procedure calls for emulsifying river substrates in a strong acid solution (i.e. ReaLemon ${ }^{\mathrm{TM}}$ juice, Borden and Co., Columbus, $\mathrm{OH}$, USA), for 10 min, then buffering the test sample to $\mathrm{pH} \mathrm{6-7}$ by the addition of an appropriate amount of sodium hydroxide $(10 \mathrm{~N} \mathrm{NaOH})$ solution. A variety of acids and buffers were also tested for use as possible reagents under local field conditions. All reagents were cross-tested to confirm the absence of mercury contaminants. Field results were later confirmed by repeating the tests under more stable conditions at the Instituto Nacional de Pesquisas da Amazônia (INPA) station in Boa Vista.

Samples of river sediment were taken along the edges of banks, shallow muddy stream beds and at eddies where sediments collect as rivers or streams meander through forested

Table 3. Brazil study localities localities for Roraima, included in caiman lead determination studies

\begin{tabular}{llll}
\hline Location & State & River & Locality \\
\hline 38 & Roraima & Rio Branco & Boa Vista \\
39 & Roraima & Rio Branco & Ilha Saõ Jose \\
40 & Roraima & Rio Branco & Praia do Brazi1* \\
41 & Roraima & Rio Ajarahj & Ilha da Viura* \\
42 & Roraima & Rio Parime & Igarape Xipitiba \\
43 & Roraima & Rio Cararuau & Rio Cararuau \\
44 & Roraima & Rio Cauame & Rio Cauame \\
45 & Roraima & Rio Iguarape & Iguarape \\
46 & Roraima & Rio Mucajai/lower & Cachoeirimha 1 \\
47 & Roraima & Rio Mucajai/mouth & Cachoeirimha 2* \\
48 & Roraima & Rio Sumaru & Sumaru \\
49 & Roraima & Rio Urariquera & Ilha de Maraca \\
50 & Roraima & Rio Urariquera & Rio Urariquera \\
51 & Roraima & Rio Urariquera & Passarao \\
\hline
\end{tabular}

* Sites tested positive for mercury.

Sources: Brazaitis et al. (1988, 1990,1992); Odierna, (unpublished). 
areas. Three $50-\mathrm{ml}$ samples containing river sediments, mud and water, from each of three localities tested, were placed in a plastic container into which 3-10 $\mathrm{ml}$ of locally obtained sulphuric acid $\left(\mathrm{H}_{2} \mathrm{SO}_{4}\right)$ was added in an approximately $5: 1$ ratio, stirred for $5 \mathrm{~min}$, allowed to settle for $10 \mathrm{~min}$, filtered through Whatman No. 3 filter paper, and then buffered to $\mathrm{pH} \mathrm{6-7} \mathrm{by} \mathrm{the} \mathrm{addition} \mathrm{of} \mathrm{the} \mathrm{appropriate}$ amount of $\mathrm{NaHCO}_{3}$ solution. Two ml of extract were then tested with a prepared mercury detection swab, according to the manufacturer's protocol. At least two swabs were tested on each sample. Any reactive colour change was noted and photographed.

\section{Observations}

All regions visited (Tables 2 and 3) had been subject to one or more adverse factors. In most instances, several environmental, socio-economic or commercially motivated factors were observed to have adverse or threatening impacts on caiman populations of all species and their habitats.

\section{Aquatic habitat destruction}

Gold-mining activities using mercury extraction techniques were observed or reported by local people in 38 localities (Table 2) in the states of Acre (loc. 1), Amapá (loc. 2-4), Amazonas (loc. 6), Goiás (loc. 13, 14), Mato Grosso (loc. 21-30), Pará (loc. 31), Piauí (loc. 32-35), Rondonia (loc. 36-37) and Roraima (Table 3, loc. 38-51), but were not observed during surveys in the lower Rio Negro in the state of Amazonas and Maranhão. Extensive mineral mining was observed in Amapá, and bauxite mining and land destruction in the Carajás region. Extensive habitat destruction and mercury pollution attributed to mining activity was observed at 19 localities in the northern regions of the state of Mato Grosso (loc. 21-26) and in Roraima (loc. 38-51).

Extensive pollution of the Rio Madeira and its associated aquatic ecosystems have been reported by Malm et al. (1990). Current investigations observed extensive waste dumping and pollution from chemical plants, petrochemical processing sites and discarded toxic wastes on the Rio Madeira from Abuna on the Bolivian border with Brazil, through Porto Velho to Humaita and beyond in Rondonia (loc. 36). The few caiman (0.18 caiman per $\mathrm{km}$ surveyed) that were captured in this region were emaciated, algae-covered, exhibited generally poor body condition and were infected with numerous leeches (class: Hirudinea) and other internal and external body parasites.

Buffalo ranching in all wetland areas, particularly regions of coastal mangrove (G. Rebêlo, pers. comm.), is highly destructive to aquatic habitats. The uprooting and breaking of aquatic vegetation increases saltwater incursions during high tides, causing increased fish mortality. This is particularly true during dry seasons, when freshwater levels are at their lowest.

\section{Toxic heavy metal pollution}

Of 14 locations (Table 3, loc. 38-51) investigated on the Rio Branco and its tributaries in the northern and central regions of the state of Roraima (Figure 1), three (loc. 40, 41, 47) were tested for mercury contamination and all were found to be positive for the presence of extractable mercury at concentrations greater than $2 \mu \mathrm{g}$ (in $10 \mathrm{ml}$ samples of river sediments $\geq 200$ p.p.m.) at sites in the vicinity of active or recent gold-mining operations.

\section{Deforestation}

Deforestation was observed at 19 localities (Table 2), especially in Amapá (loc. 2-4), northern Mato Grosso (loc. 21-30) and Maranhão (loc. 15-20). Destructive forestry practices, cattle ranching and extensive soybean monocultures were important factors. Extensive habitat destruction was ongoing and particularly evident in six localities in Maranhão (loc. 15-20).

\section{Human incursions}

The movement of human settlements into previously uninhabited areas throughout north- 
ern Brazil was noted to be closely associated with the apparent disappearance of caiman or the presence of only small populations. This is a subjective observation. Deforestation, timber-processing plants and destructive forestry practices were most often found to be associated with mining operations, cattle ranching and homesteading, and extensive soybean monocultures. Gold-mining operation sites, as well as housing camps for miners, staging areas for equipment, and poorly constructed service roads, all require new accesses through the forest. Boats and miners are frequently hauled by truck over forest roads, to allow access for miners to travel within a given regional river drainage system. Access roads are simply bulldozed through the forest, and soon become useless and inaccessible during the rainy season, necessitating the construction of other roads within several months.

These threats could affect adversely all crocodilian species in those regions, and black caiman in particular. Black caiman appear to be particularly sensitive to environmental changes (Aguirre, 1956), and are large, relatively conspicuous animals (Brazaitis, 1973). The species grows relatively slowly (Herron, 1985 ) and only begins to reproduce at 10-12 years of age when more than $2 \mathrm{~m}$ long. It tends to be less wary than other caiman species and thus is highly susceptible to local and commercial hunting pressures. Once black caiman populations are depleted, they appear to not recover easily (Rebêlo and Magnusson, 1983). Populations are widely depleted and fragmented throughout Brazil (Plotkin et al., 1983; Thorbjarnarson, 1992; Brazaitis et al., 1996). Drug trafficking and manufacture in the region of Guajara Mirim on the Rio Mamore in Rondonia were reported by local fishermen to have replaced commercial caiman hunting because they were economically more lucrative. Caiman, other than Melanosuchus, populations in this region may be recovering from past exploitation.
Commercial and subsistence hunting, and illegal trade

The influx of gold miners into remote areas sharply increases the pressure on caiman populations as a source of food for human consumption. Extensive commercial and subsistence hunting were reported by government biologists, foresters, fishermen and local people at 21 localities (Table 2) in Amapá (loc. 2-40), Amazonas (loc. 5-12) Maranhão (loc. 15-20) and Piauí (loc. 32-35). The economically depressed human populations of Amapá Amazonas, Maranhão and Piauí commonly eat caiman meat and eggs. Local people supply hide buyers with skins for money or goods. Local people, boatmen and parks officers in border and larger river towns reported a significant, well-established trade in caiman skins and meat from Amazonia. Caiman and Melanosuchus are indiscriminately taken.

Melanosuchus niger was once commonly observed in great numbers throughout the Amazon basin (Bates, 1864). Local people and the current investigators believe that commercial hunting within the last 60 years has been responsible for reducing $M$. niger populations in Amazonia and central Brazil to the present critically endangered and depleted condition (Medem, 1983; Plotkin et al., 1983; Thorbjarnarson, 1992).

\section{Discussion}

\section{Toxic heavy metal contamination}

Increased gold-mining, or garimpos, activities are associated with loss of habitats. Considering the large numbers of immigrant miners who are attracted to otherwise remote and inaccessible regions in search of work and the stability of a gold-based economy, extirpated or depleted caiman populations are to be expected. Family economies in rural regions can be supplemented with the product of subsistence hunting, gathering of forest crops and selling gold.

Gold-mining operations take place mostly in the riverbanks and sediments at the headwaters of virtually all river systems. The de- 
struction, or at best alteration, of the region is inevitable. Gold lies in deposits of gravel, sediment and quartz-bearing rock, which are excavated by hand or high-pressure pumps using water from rivers and streams, then blasted out of the ground by the use of explosives, or dredged from the river bed in huge quantities. Garimpos camps use firewood, cut from local forests, both for personal use and the gold-extraction process, resulting in extensive deforestation.

The use of mercury is one of the most efficient, inexpensive and widespread means of extracting even poor concentrations of gold from ores. Crushed gold-bearing ore is combined with mercury in a rotating drum, where amalgamation takes place. Impurities and other minerals float upon the mercury, while the gold settles out. A first separation takes place as the resulting amalgam is washed. Mercury is then wrung out of the matrix by hand, through cotton cloth. The mercury/gold amalgam is heated to drive off the mercury as vapour. The remaining gold still contains up to 5 per cent mercury, and is heated to a higher temperature to drive off the remaining mercury (Hoffmann, 1994). Environmental contamination with mercury takes place as mercury-contaminated ore is discarded to erode and leach back into the watershed, as the ore and amalgam washwater and effluents are returned to the watershed, and each time mercury vapour is liberated into the atmosphere. Mercury contamination has been identified up to $200 \mathrm{~km}$ downstream of the nearest gold-mining operations (Malm et al., 1990).

Mercury contamination of the habitat in Brazil is well known (Hoffmann, 1994) and methylmercury has already been identified as a serious health problem for indigenous people, miners and humans who are dependent on local habitats for food and water (Malm et al., 1990; Anon., 1992). Four hundred Kayapo Indians and gold miners in the southeastern region of the state of Pará, the Xingú river drainage, the villages of Gorotire and Kikretum (Table 2, region of loc. 31), were examined for methylmercury contamination in blood, hair and urine samples. One hundred per cent of the Indians and 90 per cent of the miners had high concentrations of methylmercury (Anon., 1992).

Lead contamination of habitats, ecosystems and aquatic animals is another problem. Lead levels higher than 500 p.p.b. in fish indicate a threat to aquatic environments and constitute a serious level of concern (Walsh et al., 1977). Elevated lead levels in captive crocodilians appear to affect fecundity and general health (Cook et al., 1989). Preliminary data on lead contamination in caiman tissue and meat, derived from biological samples collected during the course of these field investigations, were obtained at Manhattan College, Bronx, NY, USA, in a separate collaborative study, using atomic absorption techniques (Odierna, undated). These data suggest that lead contaminants in the habitat may be carried up through the aquatic food chain to the higher predators, such as the caiman, which feed heavily on fish and crustaceans. Two-hundred and twentyseven Brazilian C. c. crocodilus and C. yacare were sampled from regions associated with intensive gold-mining (Figure 2) operations; 17.6 per cent of the animals sampled contained lead levels below the detection level of 10 p.p.b., 33.5 per cent contained 10-500 p.p.b., 34.4 per cent contained 500-2000 p.p.b. and 14.5 per cent contained levels in excess of 2000 p.p.b. Lead levels as high as 84.0 p.p.m. were found in sampled caiman skin and liver (Odierna, undated). The precise source of lead contamination in caiman in Brazilian goldmining regions is as yet unknown, but lead may be liberated from associated ores during excavation, or may be associated with the greatly increased use of motor boats to transport miners and equipment, pumps and leaded fuels.

Gold-mining activities result in increased human population numbers in regions subject to significant and often increasing lead and mercury contamination of the aquatic environment, and inadvertently increase the rate of consumption of contaminated meat by the human population. Gold-mining activities pose a twofold threat to caiman populations: increased contamination with toxic heavy metal byproducts and increased predation. Although evidence continues to mount to 


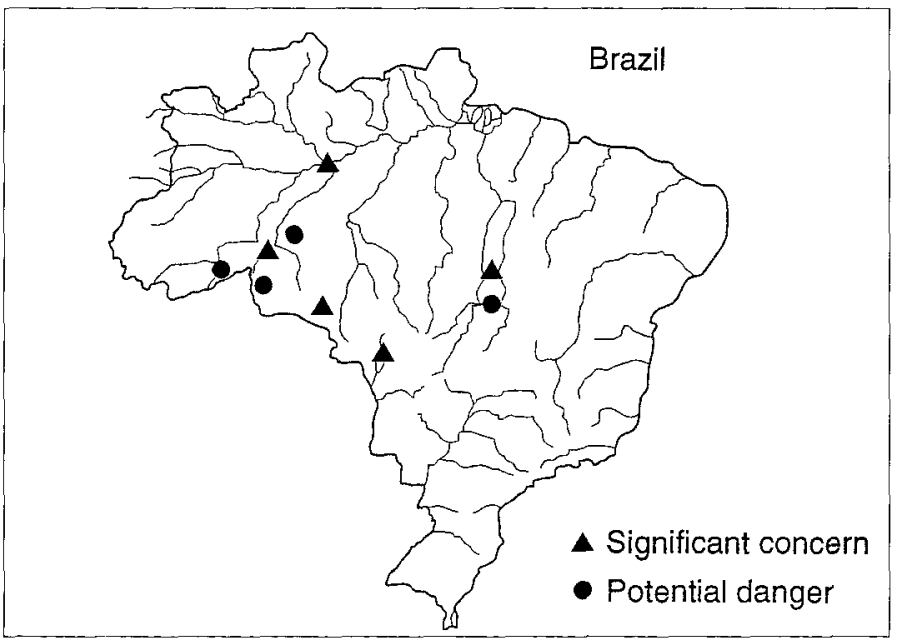

Figure 2. Map of Brazil indicating regions and levels of lead contamination identified from caiman skin and tissue samples collected during Brazilian field surveys (Brazaitis et al., 1988, 1990, 1992). warn of a potential toxic metal disaster, often little is done to protect people or the environment from contamination and the threat it represents. Caiman meat for foreign human consumption as a source of protein and as a gourmet item, and untanned skins for the manufacture of leather goods, are increasingly being promoted and exported to world markets. The short- and long-term effects of mercury and lead contamination and toxicosis on crocodilian populations is yet unknown. However, it is reasonable to assume that a serious threat exists to those species' well-being and to the continued viability of populations, particularly when toxic metal contamination coincides with increased hunting pressures and other environmental degradation.

\section{Hunting, commercial trade, wildlife law enforcement}

Illegal commercial and legal subsistence hunting were extensive throughout the study regions. The illegal trade in Caiman and $M$. niger skins and the use of caiman meat of all species for human consumption continues to flourish throughout much of northern Brazil. While caiman species occurring in Brazil are also seen in international trade (Gaski and Hemley, 1988), no conservation programme has yet been implemented in Brazil that effectively addresses the increasing hunting and environ- mental pressures that affect wild caiman populations and their habitats. The enforcement of regulations is difficult and is compounded by the limited resources available to national wildlife enforcement agencies.

Current Brazilian regulations (Edict No. 126, 13 February 1990) have established policies for captive-breeding programmes. Only in recent years have the first legal exports of raw and tanned caiman skins, documented from the production of farms or ranches in Mato Grosso do Sul, appeared in commercial trade. However, while farming and ranching operations develop, the poaching of all commercially valuable caiman species continues in many regions. Higher prices received for caiman skins emanating from ranches and farms, in the absence of a strong national wildlife-law-enforcement programme, may inadvertently increase the incentive to take more skins from wild populations. Taking wildcaught skins requires little investment and results in immediate profit. Less efficiently operated and poorly monitored farms and ranches can also place added pressures on wild populations in order to augment breeding and rearing stocks.

Illegally taken skins from wild Brazilian populations (Rebêlo and Magnusson, 1983) of caiman species are now moved across Brazilian borders into adjoining countries and may then be exported into the international 
commercial trade, bearing 'legal' tags and documentation from re-exporting countries. Similarly, legally and illegally acquired, farmed and wild-caught Brazilian caiman skins may remain undetected when mixed with those of other species from other regions in international trade and when they are manufactured into products (Brazaitis, 1989). Identification tags, which are placed on commercial skins and are designed to facilitate the monitoring of their course in trade, are affixed to the skins after tanning and prior to export. They do not necessarily reflect the actual point of origin where the caiman was killed. Depending on the part of the animal's body used in unmarked manufactured products, similarity of appearance problems may preclude the identification of a great many Brazilian caiman. The illegal international traffic in Brazilian caiman skins and meat continues to be facilitated, to the detriment of wild caiman populations.

\section{Conclusions}

The major threats contributing to the decline of Brazilian caiman populations are: commercial and subsistence hunting, gold mining garimpos activities, deforestation, extensive agriculture and destructive forestry, increased human incursions into caiman habitat, and quite possibly deleterious levels of toxic metal contamination. As a consequence of gold mining and mercury-based extraction techniques, as well as other yet unknown factors, there appears to be considerable heavy metal contamination of the aquatic habitat with mercury and lead, which may be carried up through the food chain and can be detected in crocodilian tissues in levels regarded as of serious concern. Further investigations to assess and quantify the extent of toxic metal contamination and the effect on endangered and threatened caiman populations, and on people who consume them, are urgently needed, particularly in the habitat of the already critically endangered black caiman. Comparable investigations should be done in other countries where caiman populations exist in regions where mercury is used in gold-mining and extraction procedures. The problem of heavy metal contamination must be considered in assessing any potential for increasing world-wide use of all Brazilian crocodilians, particularly for human consumption. The domestic use or export of Brazilian caiman meat for human consumption and raw skins should be discouraged, and the import of such products into the USA and other world markets should be considered carefully and cautiously.

$M$. niger is in urgent need of special conservation programmes, research and effective national and international protection. Efforts to encourage commercial incentives for expanding trade in this species should not be undertaken in the absence of adequate protection for wild populations in Brazil and other range states.

C. c. crocodilus may well be considered a threatened species throughout Brazil and possibly endangered in some regions (Brazaitis et al., 1996). Wild populations and their habitats must be closely monitored, and the present trade in the species limited, or in some cases even banned, in the absence of effective protection and monitoring programmes at national and international levels for wild populations. Considerable research on the status and composition of wild populations is essential.

\section{Acknowledgements}

This study could not have taken place without the tireless assistance, planning and efforts of the Brazilian investigators. George Rebêlo, Instituto Nacional de Pesquisas da Amazônia (INPA) and Carlos Yamashita, Instituto Brasileiro do Meio Ambiente e dos Recursos Naturais Renovaveis (IBAMA) co-ordinated and assisted in every aspect of the primary field studies. We thank the World Wildlife Fund, TRAFFIC USA, Ginnette Hemley; The Wildlife Conservation Society, Richard Lattis, John Behler and George Schaller; Myrna Watanabe; Ted Joanen; Dennis Curley; the US Fish and Wildlife Service, S. A. William Donato and S. A. John Meehan; Instituto Nacional de Pesquisas da Amazônia (INPA), Celso Morato de Carvalho, Arnaldo Carneiro Filho, Gloria Moreira, Jansen Zuanon, Jose Antonio Gomes and especially Olavo 
de Oliveira; Fundacao Estadual do Meio Ambiente (FEMA), Guilherme Borges, Anacleto Arruda Filho and Julio Dalponte; the Museu Nacional do Rio de Janeiro, Ulisses Caramaschi; Instituto Brasileiro do Meio Ambiente e Dos Recursos Naturais Renovaveis (IBAMA). Our most sincere thanks to the people of Brazil for extending to us the utmost in graciousness and hospitality.

\section{References}

Aguirre, A. 1956. Contribuicao Pará o estudo da biologia do jacare-acu Melanosuchus niger (Spix). Ministerio da Agricultura, Divisao de Caca e Pesca, Rio de Janeiro, Brazil.

Anon. 1992. Mercury used by mines contaminates two villages. The Rainforest Foundation, 10 July.

Bates, H.W. 1864. The Naturalist on the River Amazon, Everyman's Library. John Murray Publishers, London and New York.

Brazaitis, P. 1973. The identification of living crocodilians. Zoologica, 58, 59-101.

Brazaitis, P. 1989. The trade in crocodilians. In Crocodiles and Alligators (ed. A. Ross). pp. 196-201. Weldon Owen Pty Ltd, NSW, Australia.

Brazaitis, P. 1990. Trade in crocodilian hides and products in the United States. TRAFFIC USA, 10 (2), 4-5.

Brazaitis, P., Yamashita, C. and Rebêlo, G. 1988. CITES Central South American caiman study. Phase I: Central and Southern Brazil. Preliminary report to the CITES Secretariat.

Brazaitis, P., Yamashita, C. and Rebêlo, G. 1990. A summary report of the CITES central South America caiman study. Phase $\mathrm{Y}$ : Brazil. In Crocodiles. Proc. 9th. Working Meeting of the Crocodile Specialist Group, 1, 100-115. IUCN, Gland, Switzerland (unedited).

Brazaitis, P., Rebêlo, G. and Yamashita, C. 1992. The WWF/TRAFFIC USA Survey of Brazilian Amazonia Crocodilians: Survey Period July 1988 to January 1992. Unpublished report.

Brazaitis, P., Rebêlo, G. and Yamashita, C. 1996. In press. The status of Caiman crocodilus crocodilus and Melanosuchus niger populations in the Amazonian regions of Brazil. Amphibia-Reptilia.

Carvalho, A.L. 1951. Os Jacarés do Brasil. Arquizos do Museu Nacional (Rio de Janeiro), 42 (1), 125-139.

Cook, R.A., Behler, J. and Brazaitis, P. 1989. Elevated heavy metal concentrations in captive crocodilians. Proc. Annu. Meet. Am. Assoc. Zoo Vet. WR217,151.

Gaski, L. and Hemley, G. 1988. The ups and downs of the crocodilian skin trade. TRAFFIC USA, 8 (1), 1-14.

Herron, J.C. 1985. Population status, spatial relations, growth, and injuries in black and spectacled caiman in
Cocha Cashu. BA thesis. Princeton University Princeton, NJ.

Hoffmann, R. 1994. Winning gold. American Scientist, 82 (1), 15-17.

Malm, O., Pfeiffer, W.C., Souza, C.M.M. and Reuther, R. 1990. Mercury pollution due to gold mining in the Madeira River basin, Brazil. Ambio, 19, 11-15.

Medem, F. 1983. Los Crocodylia de Sur America. Vol. 2. Universidad Nacional de Colombia and Colciencias, Bogotá, Colombia.

Odierna, E. Unpublished. The occurrence of lead in Brazilian caiman as determined by atomic absorption spectrometry: a potential ecological disaster. MSc thesis. Department of Biology, Manhattan College, Bronx, New York.

Plotkin, M., Medem, F., Mittermeier, R.A. and Constable, I.D. 1983. Distribution and conservation of the black caiman (Melanosuchus niger). In Advances in Herpetology and Evolutionary Biology (eds A. G. J. Rhodin and K. Miyata), pp. 695-705. Museum of Comparative Zoology, Cambridge, Mass.

Rebêlo, G. and Magnusson, W.E. 1983. An analysis of the effect of hunting on Caiman crocodilus and Melanosuchus niger, based on the size of confiscated skins. Biol. Cons. 26, 95-104.

Roeper, N. and Hemley, G. 1984. Crocodile and alligator trade by the United States. In Crocodiles: Proceedings 6th Working Meeting of the Crocodile Specialist Group. pp. 122-147. IUCN, Gland, Switzerland.

Thorbjarnarson, J. 1992. Crocodiles: An Action Plan for their Conservation. IUCN, Gland, Switzerland.

Walsh, D., Berger, B.L. and Bean, J.R. 1977. Residues in fish, wildlife and estuaries. Mercury, arsenic, lead, cadmium and selenium residues in fish, 1971-73. National pesticide monitoring program. Pesticides Monitoring Journal, 11, 5-34.

Yanosky, A.A. 1994. A population of Caiman latirostris at $800 \mathrm{~m}$ above sea level. Bull. of the Maryland Herpetological Society, 30 (3), 108-113.

Peter Brazaitis, Central Park Wildlife Center, 830 Fifth Ave, New York, NY 10021, USA.

George H. Rebêlo, Instituto de Pesquisas da Amazônia, Depart. Ecologia, CXP 478, 69.000, Manaus-AM, Brazil.

Carlos Yamashita, Rua Voluntarios da Patria 3714, CEP 02402, São Paulo, SP, Brazil.

Elizabeth A. Odierna, Montefiore Medical Center, 111 E 210th St, Bronx, NY 10467, USA.

Myrna E. Watanabe, Biological Sciences, Old Dominion University, Norfolk, VA 23529, USA. 